\title{
MEK signaling modulates sodium iodide symporter at multiple levels and in a paradoxical manner
}

\author{
Douangsone D Vadysirisack ${ }^{1,3}$, Anjli Venkateswaran ${ }^{2,3}$, Zhaoxia Zhang ${ }^{2,3}$ \\ and Sissy M Jhiang 1,2,3,4
}

\footnotetext{
${ }^{1}$ Integrated Biomedical Science Graduate Program, The Ohio State University, Columbus, Ohio, USA

${ }^{2}$ The Ohio State Biochemistry Program, The Ohio State University, Columbus, Ohio, USA

${ }^{3}$ Department of Physiology and Cell Biology, The Ohio State University, Columbus, Ohio, USA and

${ }^{4}$ Department of Internal Medicine, The Ohio State University, Columbus, Ohio, USA

(Requests for offprints should be addressed to S M Jhiang who is now at 304 Hamilton Hall, 1645 Neil Avenue, The Ohio State University, Columbus, Ohio 43210, USA; Email: jhiang.1@osu.edu)
}

\begin{abstract}
The $\mathrm{Na}^{+} / \mathrm{I}^{-}$symporter (NIS)-mediated iodide uptake is the basis for targeted radioiodine ablation of thyroid cancers. However, NIS-mediated radioiodide uptake (RAIU) activity is often reduced in thyroid cancers. As mitogen activated protein kinase (MAPK) signaling pathway is activated in about $70 \%$ of papillary thyroid carcinoma, we investigated whether MEK (MAPK kinase) inhibition will restore NIS protein levels and NIS-mediated RAIU activity in RET/PTC oncogene-transformed thyroid cells. We found that MEK inhibitor PD98059 increased NIS protein levels within 30 min of treatment. However, the increase of NIS protein level was not accompanied with an increase in NIS-mediated RAIU activity, particularly at early time points of PD98059 treatment. PD98059 also decreased RAIU activity mediated by exogenous NIS in non-thyroid cells. The transient decrease of RAIU activity by PD98059 in thyroid cells was not due to decreased NIS cell surface level, decreased NIS binding affinity for $\mathrm{I}^{-}$, or increased iodide efflux. While PD98059 moderately decreased $\mathrm{Na}^{+} / \mathrm{K}^{+}$-ATPase activity, ouabain titration indicates that the extent of decrease in $\mathrm{Na}^{+} / \mathrm{K}^{+}$-ATPase activity is much greater than the extent of decrease in RAIU activity. Additionally, a decrease of $\mathrm{Na}^{+} / \mathrm{K}^{+}$-ATPase activity was not accompanied with a decrease of biotin uptake activity mediated by $\mathrm{Na}^{+}$-dependent multivitamin transporter. Since PD98059 reduced $V_{\max }-\mathrm{I}^{-}$without decreasing NIS cell surface levels, it is most likely that PD98059 decreases the turnover rate of iodide transport with an yet to be identified mechanism.
\end{abstract}

Endocrine-Related Cancer (2007) 14 421-432

\section{Introduction}

$\mathrm{The}^{+}{ }^{+} / \mathrm{I}^{-}$symporter (NIS) is an intrinsic membrane glycoprotein that mediates active iodide uptake into thyroid follicular cells for synthesis of iodidecontaining thyroid hormones. NIS co-transports one $\mathrm{I}^{-}$ion against its concentration gradient along with two $\mathrm{Na}^{+}$ions down their concentration gradient into cells (Eskandari et al. 1997). The $\mathrm{Na}^{+}$electrochemical gradient, which is maintained by $\mathrm{Na}^{+} / \mathrm{K}^{+}$-ATPase activity, provides the driving force for NIS to transport iodide against its concentration gradient. NIS-mediated iodide concentrating activity is the molecular basis for the post-operative use of radioiodine in the detection and targeted ablation of residual, recurrent, and metastatic thyroid cancers. However, NIS expression, as well as NIS-mediated radioiodide uptake (RAIU) activity, is lost in some patients with advanced thyroid cancers, such that these patients cannot benefit from radioiodine imaging and therapy (Arturi et al. 1998, Lazar et al. 1999, Arturi et al. 2000). It is therefore clinically significant to devise strategies to increase NIS expression and activity in the thyroid tumors of these patients.

The RET/PTC1 chimeric oncogene, formed by the intrachromosomal rearrangement of the RET receptortype tyrosine kinase proto-oncogene with the $\mathrm{H} 4$ gene, is frequently found in papillary thyroid carcinomas (for review, see Jhiang 2000). RET/PTC1 has been shown 
to reduce NIS expression and radioiodine concentrating activity in thyroid tumors of transgenic mouse model (Jhiang et al. 1998, Cho et al. 1999, Buckwalter et al. 2002) as well as in cultured thyroid cells (Trapasso et al. 1999, Venkateswaran et al. 2004). Recently, it has been reported that RET/PTC oncoprotein reduces NIS mRNA levels in $\mathrm{PCCl} 3$ rat thyroid cells through the Shc/Ras/MAPK signaling pathway (Knauf et al. 2003). The authors also showed that MAP/ERK kinase (MEK) (MAPK kinase) inhibitors restored NIS mRNA levels in $\mathrm{PCCl} 3$ cells expressing RET/PTC. Thus, we hypothesized that MEK inhibition will restore NIS protein levels and facilitate NISmediated RAIU activity in RET/PTC-transformed thyroid cells and potentially in other papillary thyroid tumors harboring Ras or B-Raf genetic alterations.

In this study, we investigated the effects of MEK inhibition on both NIS protein levels and NIS-mediated RAIU activity in $\mathrm{PCCl} 3$ rat thyroid cells, $\mathrm{PCCl} 3$ cells stably expressing RET/PTC1, PCCl3 cells with doxycycline-inducible expression of constitutively active MEK1, as well as in COS7 cells expressing exogenous NIS. We showed that treatment of PD98059 increased endogenous NIS protein levels in thyroid cells, yet decreased RAIU activity mediated by either endogenous or exogenous NIS. Efforts made to identify the mechanism(s) underlying the decrease of RAIU activity by MEK inhibition excluded the possible effects of MEK inhibition on NIS cell surface trafficking, NIS binding affinity for $\mathrm{I}^{-}$, or iodide efflux. Taken together, our study uncovers an yet to be identified mechanism that modulates NIS-mediated RAIU activity by MEK signaling and MEK signaling appears to regulate NIS at multiple levels and in a paradoxical manner.

\section{Materials and methods}

\section{Cell culture}

$\mathrm{PCCl} 3$ rat thyroid cells were maintained in Kaighn's medium (Sigma), 5\% calf serum, $2 \mathrm{mM}$ glutamine, $1 \%$ penicillin-streptomycin, $10 \mathrm{mM} \mathrm{NaHCO}$, and $6 \mathrm{H}$ hormone ( $1 \mathrm{mU} / \mathrm{ml}$ bovine thyrotropin, $10 \mu \mathrm{g} / \mathrm{ml}$ bovine insulin, $10 \mathrm{nM}$ hydrocortisone, $5 \mu \mathrm{g} / \mathrm{ml}$ transferrin, $10 \mathrm{ng} / \mathrm{ml}$ somatostatin, and $2 \mathrm{ng} / \mathrm{ml} \mathrm{L-glycyl-histidyl-}$ lysine). $\mathrm{PCCl} 3$ cells stably expressing RET/PTC1 were generated as described (Venkateswaran et al. 2004). PCCl3 cells with doxycycline-inducible MEK1 (E217/ E221) expression (kindly provided by Drs Jeffrey A Knauf and James A Fagin, University of Cincinnati) were induced with $2 \mu \mathrm{g} / \mathrm{ml}$ doxycycline for $48 \mathrm{~h}$. COS7 monkey kidney cells were maintained in DMEM with $10 \%$ fetal bovine serum and $1 \%$ penicillin-streptomycin, and were transfected with rat NIS cDNA or human SMVT cDNA (kindly provided by Dr Puttur D Prasad, Medical College of Georgia) using FuGENE 6 (Roche).

\section{RAIU assay}

Steady-state radioiodide accumulation was determined as follows. Cells were treated with DMSO or PD98059 (Promega) for $4 \mathrm{~h}$, and then incubated with $2 \mu \mathrm{Ci} \mathrm{Na}{ }^{125} \mathrm{I}$ in $5 \mu \mathrm{M}$ non-radioactive $\mathrm{NaI}$ for $30 \mathrm{~min}$ at $37^{\circ} \mathrm{C}$ with $5 \% \mathrm{CO}_{2}$. Subsequently, cells were washed twice with cold Hank's balanced salt solution (HBSS) and lysed with $95 \%$ ethanol for $20 \mathrm{~min}$. The cell lysate was collected and radioactivity was counted by a gammacounter. Experiments were performed in triplicate.

\section{lodide-dependent kinetic analysis}

Initial rate of iodide uptake and binding affinity of substrate iodide was determined as described (Dohan et al. 2002). Cells were treated with DMSO or PD98059 for $4 \mathrm{~h}$, and then incubated for $2 \mathrm{~min}$ with varying concentration of $\mathrm{NaI}$ (eight concentrations ranging from 1 to $400 \mu \mathrm{M}$ ) containing $\mathrm{Na}^{125}$ I of a specific activity of $80 \mathrm{mCi} / \mathrm{mmol}$. The amounts of accumulated iodide were measured as described for RAIU assay. The $K_{\mathrm{m}}$ and $V_{\max }$ values for $\mathrm{I}^{-}$were derived from fitted Michaelis-Menten equation according to the EadieHofstee plot. Experiments were performed in triplicate.

\section{lodide efflux assay}

Efflux of ${ }^{125}$ I was performed as described (Marsee et al. 2004). Cells were treated with DMSO or PD98059 for $4 \mathrm{~h}$ and then incubated in media containing $\mathrm{Na}^{125} \mathrm{I}$ as described for RAIU assay. Cells were washed twice and incubated with $1 \mathrm{ml}$ HBSS. After $2 \mathrm{~min}$, the medium was collected and replaced with HBSS. This was repeated every $2 \mathrm{~min}$ for a total of $10 \mathrm{~min}$. Cells were then lysed with $95 \%$ ethanol for $20 \mathrm{~min}$. The total uptake of each well was calculated as the sum of the efflux washes and the lysates. Experiments were performed in triplicate.

\section{Cell surface biotinylation}

Cells were treated with DMSO or PD98059 for $4 \mathrm{~h}$ and then washed with cold PBS containing $1 \mathrm{mM} \mathrm{MgCl}_{2}$ and $0.1 \mathrm{mM} \mathrm{CaCl}_{2}$ (PBS-Ca/Mg). Cells were incubated with $1 \mathrm{mg} / \mathrm{ml}$ sulfo-NHS-LC-biotin (Pierce) in PBS$\mathrm{Ca} / \mathrm{Mg}$ for $1 \mathrm{~h}$ at $4{ }^{\circ} \mathrm{C}$. The reaction was quenched with PBS-Ca/Mg containing $100 \mathrm{mM}$ glycine for $20 \mathrm{~min}$. Cells were then lysed in lysis buffer $(50 \mathrm{mM}$ Tris $(\mathrm{pH}$ 7.5), $150 \mathrm{mM} \mathrm{NaCl}, 5 \mathrm{mM}$ EDTA, $1 \%$ Triton X-100, $1 \mathrm{mM}$ PMSF, $10 \mu \mathrm{g} / \mathrm{ml}$ aprotinin, and $10 \mu \mathrm{g} / \mathrm{ml}$ 
leupeptin) for $30 \mathrm{~min}$ at $4{ }^{\circ} \mathrm{C}$. An $18 \frac{1}{2}$ gage needle was used to homogenize the cells. Lysates were centrifuged at $14000 \mathrm{~g}$ for $20 \mathrm{~min}$ at $4{ }^{\circ} \mathrm{C}$, and supernatants (whole cell lysates) were collected. Protein concentrations were determined by Bradford assay (Bio-Rad). To separate biotinylated surface proteins from nonbiotinylated proteins, whole cell lysates were incubated with avidin-coated agarose beads (Pierce) overnight at $4{ }^{\circ} \mathrm{C}$. The beads were washed with lysis buffer, and biotin-labeled proteins were eluted with $2 \times$ Laemmli sample buffer for $5 \mathrm{~min}$ at $95^{\circ} \mathrm{C}$.

\section{Western blot analysis}

Proteins were subjected to $10 \%$ SDS-PAGE and transferred to a nitrocellulose membrane. The membrane was blocked with 5\% dry milk, then incubated with one of the following primary antibodies: PA716 polyclonal rabbit anti-rat NIS (kindly provided by Dr Bernard Rousset, Institut National de la Santé et de la Recherche Médicale; diluted 1:1500), monoclonal mouse anti- $\mathrm{Na}^{+} / \mathrm{K}^{+}$-ATPase $\alpha_{1}$ (Santa Cruz Biotechnology Inc., Santa Cruz CA, USA; diluted 1:1000), polyclonal rabbit anti-phosphorylated extracellular signal-regulated kinase (ERK) (Santa Cruz; diluted 1:250), polyclonal rabbit anti-ERK (Santa Cruz; diluted 1:250), or monoclonal mouse anti- $\beta$-actin (Abcam, Cambridge, MA, USA; diluted 1:2000). Subsequently, the membrane was incubated with horseradish peroxidase (HRP)-conjugated anti-rabbit IgG (Amersham Pharmacia; diluted 1:4000) or HRPconjugated anti-mouse IgG (Cell Signaling Technology, Danvers, MA, USA; diluted 1:2500). The signal was detected by enhanced chemiluminescence detection reagents. The signal intensities were measured densitometrically using NIH Image software. To determine equal protein loading of total and cell surface NIS protein levels, as well as total and cell surface $\mathrm{Na}^{+} / \mathrm{K}^{+}$-ATPase $\alpha_{1}$ protein levels, the membrane was probed with a polyclonal rabbit antibody against V-ATPase E subunit (kindly provided by Dr Beth Lee, Ohio State University; diluted 1:1000).

\section{Ouabain-sensitive ${ }^{86} \mathbf{R b}$ uptake assay}

$\mathrm{Na}^{+} / \mathrm{K}^{+}$-ATPase-mediated ion transport activity was measured as ouabain-sensitive uptake of ${ }^{86} \mathrm{Rb}$. Cells were treated with DMSO or PD98059 for $4 \mathrm{~h}$, and then treated in the presence or absence of the specific $\mathrm{Na}^{+} / \mathrm{K}^{+}$-ATPase inhibitor ouabain $(1 \mathrm{mM}$ final concentration) for $15 \mathrm{~min}$ at room temperature. Subsequently, cells were incubated with $0.5 \mu \mathrm{Ci}{ }^{86} \mathrm{RbCl}$ in DMEM for $15 \mathrm{~min}$ at $37^{\circ} \mathrm{C}$ with $5 \% \mathrm{CO}_{2}$. Cells were washed twice with cold HBSS and then lysed with $95 \%$ ethanol for $20 \mathrm{~min}$ at room temperature. The cell lysate was collected and radioactivity was counted by a liquid scintillation counter. Ouabain-sensitive ${ }^{86} \mathrm{Rb}$ was calculated as the difference between the ${ }^{86} \mathrm{Rb}$ uptake measured in the presence and the absence of ouabain. Experiments were performed in triplicate.

\section{$\left[{ }^{3} \mathrm{H}\right]$ biotin uptake assay}

Cells were incubated with $1.5 \mu \mathrm{Ci}\left[{ }^{3} \mathrm{H}\right]$ biotin in uptake medium containing $25 \mathrm{mM}$ Hepes/Tris ( $\mathrm{pH} 7.5$ ), $140 \mathrm{mM} \mathrm{NaCl}, 5.4 \mathrm{mM} \mathrm{KCl}, 1.8 \mathrm{mM} \mathrm{CaCl}_{2}, 0.8 \mathrm{mM}$ $\mathrm{MgSO}_{4}$, and $5 \mathrm{mM}$ glucose for $30 \mathrm{~min}$ at $37{ }^{\circ} \mathrm{C}$ with $5 \%$ $\mathrm{CO}_{2}$. Cells were washed twice with cold uptake medium and then lysed with cold $95 \%$ ethanol for $20 \mathrm{~min}$ at room temperature. The cell lysate was collected and radioactivity was counted by a liquid scintillation counter. Experiments were performed in triplicate.

\section{Adenovirus-mediated dominant negative MEK1 transduction}

Cells were seeded for RAIU assay or western blot analysis $24 \mathrm{~h}$ prior to infection with recombinant adenovirus carrying LacZ or dominant negative MEK1 (A217/A221) (Cell Biolabs, Inc.). Cells were washed with PBS, incubated with $2 \% \mathrm{FBS}$, and infected with adenoviruses for $3 \mathrm{~h}$. Subsequently, cells were washed with PBS and cultured in regular medium. Forty-eight hours post-infection, RAIU assay and western blot analysis were performed.

\section{Statistical analysis}

Comparisons between groups were performed using paired $t$-test. A $P<0.05$ was considered to be statistically significant.

\section{Results}

\section{MEK inhibition increases NIS protein levels, yet decreases NIS-mediated RAIU activity in RET/PTC1-expressing thyroid cells}

To investigate the role of MEK signaling in RET/PTC1 effects on NIS expression and functional activity, we examined the effects of the pharmacological MEK inhibitor PD98059 (Alessi et al. 1995) on NIS protein levels and NIS-mediated RAIU activity in $\mathrm{PCCl} 3$ rat thyroid cells stably expressing RET/PTC1. We found that treatment of $40 \mu \mathrm{M}$ PD98059 for $4 \mathrm{~h}$ increased total NIS protein levels about twofold in RET/PTC1expressing cells (lane 1 versus lane 2 in Fig. 1A), but not evident in parental $\mathrm{PCCl} 3$ cells at $4 \mathrm{~h}$ treatment (lane 3 versus lane 4 in Fig. 1A). Unexpectedly, 


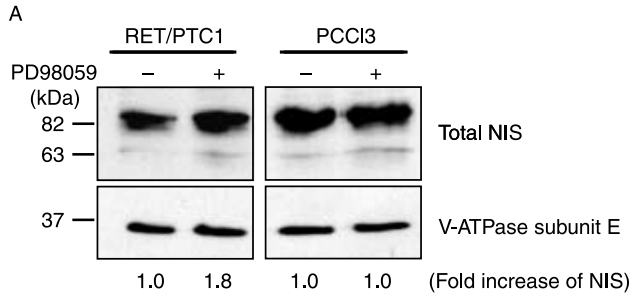

B
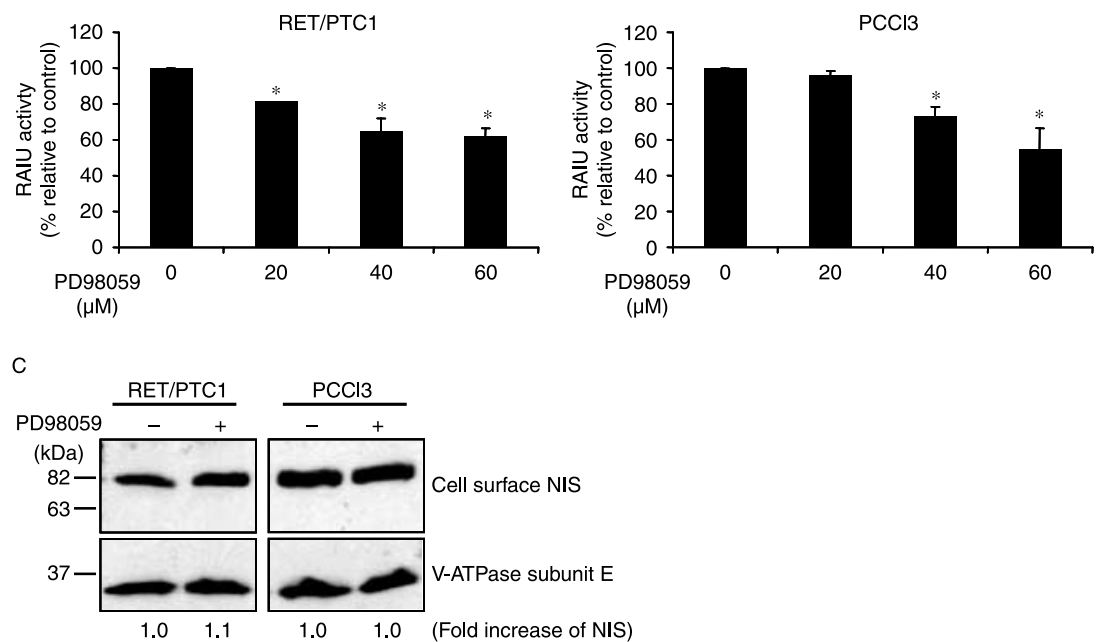

Figure $1 \mathrm{MEK}$ inhibition increases NIS protein levels, yet decreases RAIU activity without decreasing NIS cell surface levels in RET/PTC1-expressing cells and parental PCCl3 cells. A: Western blot analysis showed that treatment of $40 \mu \mathrm{M}$ PD98059 for $4 \mathrm{~h}$ increased total NIS protein levels in RET/PTC1-expressing cells, but not evident in parental PCCl3 cells. Densitometry analysis was performed to determine the fold increase of total NIS normalized with V-ATPase. The results are representative of three independent experiments. B: PD98059 decreased NIS-mediated RAIU activity at $4 \mathrm{~h}$ in a dose-dependent manner in both RET/PTC1-expressing cells and parental PCCl3 cells. Treatment of $40 \mu \mathrm{M}$ PD98059 for $4 \mathrm{~h}$ decreased RAIU activity in RET/PTC1expressing cells and parental PCCl3 cells by 35 and $27 \%$ respectively. The results represent the mean \pm s.D. of three independent experiments performed in triplicate. Asterisks denote statistically significant difference in comparison with DMSO-treated cells $(P<0.05)$. C: Treatment of $40 \mu \mathrm{M}$ PD98059 for $4 \mathrm{~h}$ did not decrease cell surface NIS levels in RET/PTC1-expressing cells or parental $\mathrm{PCCl} 3$ cells. Cell surface proteins were biotinylated and later isolated by avidin-coated beads and subjected to western blot analysis to detect cell surface NIS levels. Densitometry analysis was performed to determine the fold increase of cell surface NIS normalized with V-ATPase. The results are representative of two independent experiments.

PD98059 failed to increase NIS-mediated RAIU activity in RET/PTC1-expressing cells. Instead, PD98059 decreased RAIU activity in a dose-dependent manner in RET/PTC1-expressing cells as well as parental PCCl3 cells (Fig. 1B). Treatment of $40 \mu \mathrm{M}$ PD98059 for $4 \mathrm{~h}$ decreased RAIU activity in RET/PTC1-expressing cells and parental PCCl3 cells by 35 and $27 \%$ respectively. Similar effects on RAIU activity were observed using an alternative pharmacological MEK inhibitor, U0126 at $20-60 \mu \mathrm{M}$, in RET/PTC1-expressing cells and parental $\mathrm{PCCl} 3$ cells (data not shown).

Since it is the NIS protein localized at the cell surface, but not the total NIS protein level, that confers NIS-mediated RAIU activity, we examined the effects of PD98059 on NIS cell surface levels. Cell surface biotinylation studies showed that $4 \mathrm{~h}$ treatment of
$40 \mu \mathrm{M}$ PD98059 did not decrease NIS cell surface levels in RET/PTC1-expressing cells or parental $\mathrm{PCCl} 3$ cells (Fig. 1C). Immunofluorescence studies using confocal microscopy confirmed that PD98059 had no apparent effect on NIS cell surface expression (data not shown). Taken together, the decrease in RAIU activity by PD98059 was not contributed by a decrease in NIS cell surface levels.

\section{PD98059 increases NIS protein levels, but not NIS-mediated RAIU activity, in $\mathrm{PCCl} 3$ cells expressing constitutively active MEK}

The direct effects of MEK activation on NIS protein levels and NIS-mediated RAIU activity were investigated in $\mathrm{PCCl} 3$ cells with doxycycline-inducible MEK1 (E217/E221) expression. As expected, acute expression of constitutively active MEK1 decreased 


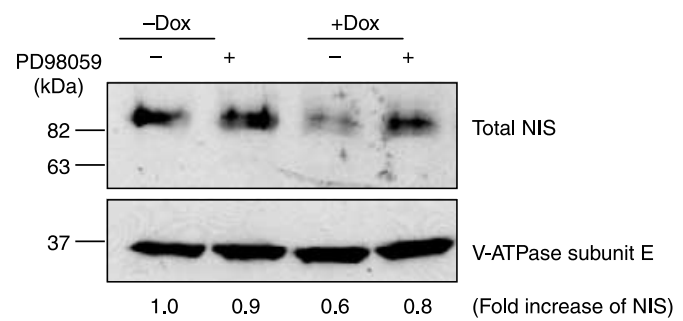

B

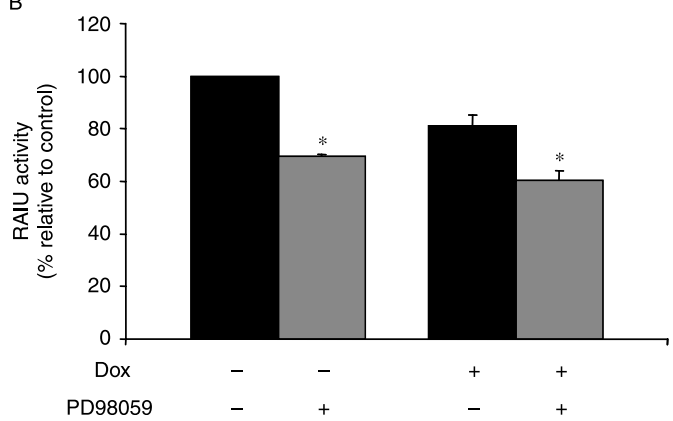

Figure 2 PD98059 increases NIS protein levels, but decreases RAIU activity, in doxycycline-inducible MEK1 (E217/E221) expressing PCCl3 cells. A: Western blot analysis showed that NIS protein levels were decreased upon doxycycline induction and that treatment of $40 \mu \mathrm{M}$ PD98059 for $4 \mathrm{~h}$ increased total NIS protein levels in doxycycline-induced MEK1 expressing cells. Densitometry analysis was performed to determine the fold increase of total NIS normalized with V-ATPase. The results are representative of two independent experiments. B: Treatment of $40 \mu \mathrm{M}$ PD98059 for $4 \mathrm{~h}$ decreased RAIU activity in non-induced and doxycycline-induced cells by 30 and $40 \%$ respectively. The results represent the average and range of two independent experiments performed in triplicate.

Asterisks denote statistically significant difference in comparison with DMSO-treated cells $(P<0.05)$.

both total NIS protein levels (lane 1 versus lane 3 in Fig. 2A) and NIS-mediated RAIU activity (Fig. 2B). We found that treatment of $40 \mu \mathrm{M}$ PD98059 for $4 \mathrm{~h}$ increased NIS protein levels in doxycycline-induced MEK1 cells (lane 3 versus lane 4 in Fig. 2A), but not in non-induced MEK1 cells (lane 1 versus lane 2 in Fig. 2A). Consistent with the finding of the effects of PD98059 on RAIU activity in RET/PTC1-expressing cells and parental PCCl3 cells, PD98059 also decreased RAIU activity in $\mathrm{PCCl} 3$ cells with doxycycline-induced MEK1 cells as well as in non-induced MEK1 cells (Fig. 2B).

\section{PD98059 increases NIS protein levels and decreases RAIU activity within $\mathbf{3 0}$ min in thyroid cells}

The temporal profile of PD98059 on NIS modulation in RET/PTC1-expressing cells and parental PCCl3 cells was investigated. PD98059 increased NIS protein levels within $30 \mathrm{~min}$ of treatment, and the increase persisted after $48 \mathrm{~h}$ treatment, in RET/PTC1-expressing cells (Fig. 3A). In comparison, PD98059 also increased NIS protein levels in parental $\mathrm{PCCl} 3$ cells but to a lesser extent (Fig. 3B). Thus, RET/PTC1-expressing cells appeared to be more sensitive to MEK inhibition on NIS increase than parental $\mathrm{PCCl} 3$ cells. As shown in Fig. 3C and 3D, PD98059 decreased RAIU activity within $30 \mathrm{~min}$ and persisted after $4 \mathrm{~h}$ treatment. However, RAIU activity was increased about $22 \%$ after $48 \mathrm{~h}$ treatment in both cell lines. Thus, the decrease of RAIU activity by PD 98059 was transient in nature for both cell lines. Nevertheless, the extent of increase on RAIU activity at 48-h treatment was not proportional to the extent of increase on NIS protein levels.

\section{PD98059 also reduces RAIU activity in cells expressing exogenous NIS, without notable changes in total or cell surface NIS levels}

To investigate whether PD98059 modulation of NIS expression and activity is restricted to thyroid cells, we examined the effects of PD98059 on NIS protein levels and RAIU activity in COS7 monkey kidney cells expressing exogenous NIS. As shown in Fig. 4A, PD98059 only slightly increased total NIS protein levels in COS7/NIS cells after $4 \mathrm{~h}$ treatment. However, PD98059 also decreased RAIU activity in COS7/NIS cells after $4 \mathrm{~h}$ treatment (Fig. 4B). Cell surface biotinylation studies showed that $4 \mathrm{~h}$ treatment of PD98059 did not decrease, but modestly increased, NIS cell surface levels in COS7/NIS cells (Fig. 4C). Thus, the decrease in RAIU activity by PD98059 was not contributed by a decrease in NIS cell surface levels. The finding that PD98059 decreased NIS-mediated RAIU activity in COS7/NIS cells indicates that PD98059 effects on RAIU activity is not restricted to thyroid cells expressing endogenous NIS.

\section{Adenovirus infection of dominant negative MEK1 increases NIS protein levels in thyroid cells and decreases RAIU activity in cells expressing exogenous NIS}

To confirm that the effects of the pharmacological MEK inhibitor PD98059 on NIS expression in thyroid cells were due to MEK inhibition, we infected RET/PTC1-expressing cells, and parental $\mathrm{PCCl} 3$ cells with recombinant adenovirus carrying dominant negative MEK1 (A217/A221). As shown in Fig. 5A, total NIS protein levels were increased about six- to sevenfold in parental PCCl3 cells and RET/PTC1expressing cells respectively after 48 -h post-infection with dominant negative MEK1. Thus, the increase of 

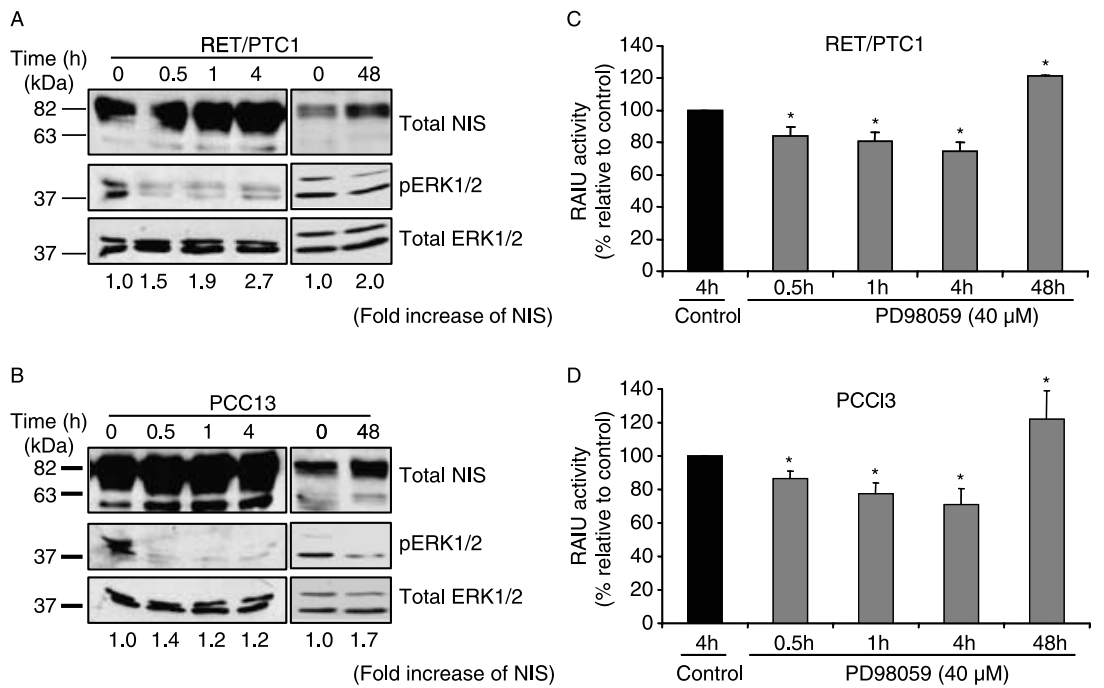

Figure 3 Temporal profile of PD98059 effect on NIS protein levels and RAIU activity in thyroid cells. RET/PTC1-expressing cells and parental PCCl 3 cells were treated with $40 \mu \mathrm{M}$ PD98059 for the indicated time. A: Western blot analysis showed the temporal kinetics of increased NIS protein levels by PD98059 in RET/PTC1-expressing cells, and B: parental PCCI3 cells. Densitometry analysis was performed to determine the fold increase of total NIS normalized with total ERK. The results are representative of two independent experiments. C: PD98059 decreased RAIU activity in RET/PTC1-expressing cells by 16, 19, and $25 \%$ at $30 \mathrm{~min}, 1 \mathrm{~h}$, and $4 \mathrm{~h}$ time points respectively. However, RAIU activity was increased by $22 \%$ after $48 \mathrm{~h}$ in RET/PTC1-expressing cells. D: PD98059 decreased RAIU activity in parental PCCI3 cells by 13,23 and $29 \%$ at $30-\mathrm{min}, 1$-h, and 4 -h time points respectively. However, RAIU activity was also increased by $22 \%$ after $48 \mathrm{~h}$ in parental PCCl3 cells. The results represent the mean \pm s.D. of three independent experiments performed in triplicate. Asterisks denote statistically significant difference in comparison with DMSO-treated cells $(P<0.05)$.

NIS protein levels by PD98059 in thyroid cells is at least in part mediated by MEK inhibition. Unfortunately, RAIU activity in both RET/PTC1-expressing cells and parental $\mathrm{PCCl} 3$ cells was reduced significantly following adenovirus infection (either with recombinant adenovirus carrying LacZ or dominant negative MEK1), which prevented us from examining the effects of rAdDNMEK1 on RAIU activity in thyroid cells. As PD98059 also decreased RAIU activity in COS7 cells expressing exogenous NIS, we infected COS7/NIS cells with rAdDNMEK1 to investigate the effects of rAdDNMEK1 on RAIU activity. We found that RAIU activity in COS7/NIS cells was reduced about 24\% following infection with rAdDNMEK1 (Fig. 5B). This suggests that the decrease in RAIU activity by PD98059 in COS7/NIS is at least in part mediated by MEK inhibition.

\section{PD98059 does not alter NIS binding affinity for iodide}

We then examined the possible effects of $4 \mathrm{~h}$ PD98059 treatment on the kinetic properties of $\mathrm{I}^{-}$uptake in RET/PTC1-expressing cells, parental $\mathrm{PCCl} 3$ cells, and COS7/NIS cells. We demonstrated that PD98059 had no apparent effect on $K_{\mathrm{m}}-\mathrm{I}^{-}$in all the three cell lines, indicating that the decrease in RAIU activity by PD98059 was not contributed by a decrease in NIS binding affinity for substrate $\mathrm{I}^{-}$(Table 1). Instead, PD98059 decreased the maximal rate of $\mathrm{I}^{-}$uptake $\left(V_{\max }-\mathrm{I}^{-}\right)$about $26-35 \%$ in these cell lines (Table 2$)$. Since PD98059 does not decrease cell surface NIS levels, it is most likely that PD98059 decreases RAIU activity by decreasing the velocity of iodide transport $\left(V_{\max }-\mathrm{I}^{-}\right)$.

\section{PD98059 does not alter the rate of iodide efflux}

Since the equilibrium of active iodide uptake and iodide efflux contributes to steady-state radioiodide accumulation, we analyzed the effects of PD98059 on the rate of iodide efflux in RET/PTC1-expressing cells and parental $\mathrm{PCCl} 3$ cells. We showed that PD98059 had no apparent effect on the rate of iodide efflux in either RET/PTC1-expressing cells (Fig. 6A) or parental $\mathrm{PCCl} 3$ cells (Fig. 6B). Thus, the decrease in RAIU activity by PD98059 was not contributed by an increase in the rate of iodide efflux.

\section{PD98059 reduces $\mathrm{Na}^{+} / \mathrm{K}^{+}$-ATPase activity}

NIS-mediated RAIU activity depends on the $\mathrm{Na}^{+}$ electrochemical gradient maintained by the $\mathrm{Na}^{+} / \mathrm{K}^{+}$ATPase. We therefore investigated the effects of PD98059 on total and cell surface $\mathrm{Na}^{+} / \mathrm{K}^{+}$-ATPase protein levels, as well as $\mathrm{Na}^{+} / \mathrm{K}^{+}$-ATPase activity in RET/PTC1-expressing cells, parental PCCl3 cells, and 
A

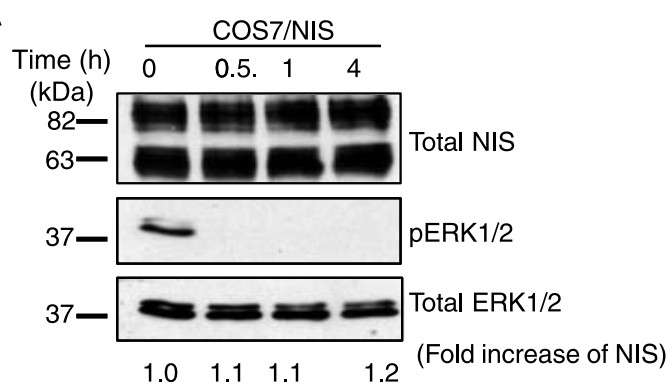

B

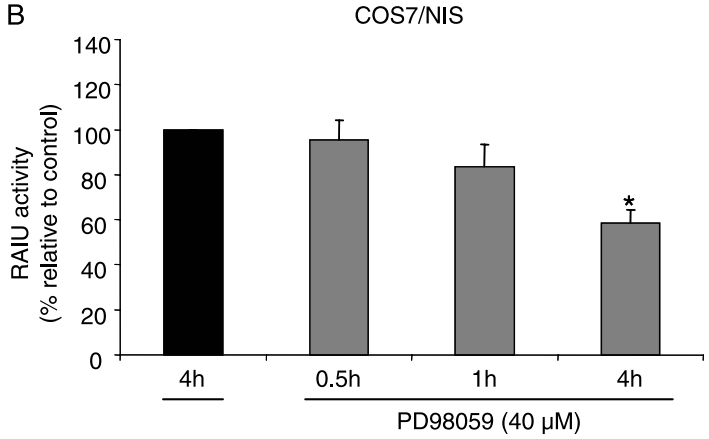

C

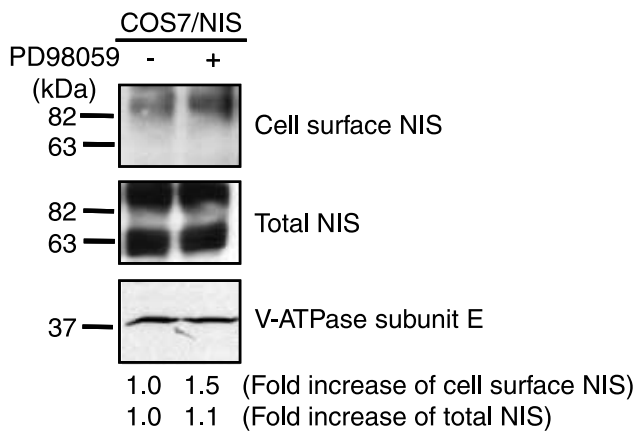

Figure 4 PD98059 decreases RAIU activity in COS7 cells expressing exogenous NIS. Cells were treated with $40 \mu \mathrm{M}$ PD98059 for the indicated time. A: Western blot analysis showed that PD98059 slightly increased total NIS protein levels in COS7/NIS cells. Densitometry analysis was performed to determine the fold increase of total NIS normalized with total ERK. The results are representative of two independent experiments. B: PD98059 decreased RAIU activity in COS7/NIS cells by $42 \%$ at the 4 -h time point. The results represent the mean \pm s.D. of three independent experiments performed in triplicate. Asterisks denote statistically significant difference in comparison with DMSOtreated cells $(P<0.05)$. C: Cell surface biotinylation showed that PD98059 treatment for $4 \mathrm{~h}$ did not decrease, but modestly increase, cell surface NIS levels in COS7/NIS cells. Densitometry analysis was performed to determine the fold increase of total or cell surface NIS normalized with V-ATPase. The results are representative of two independent experiments.
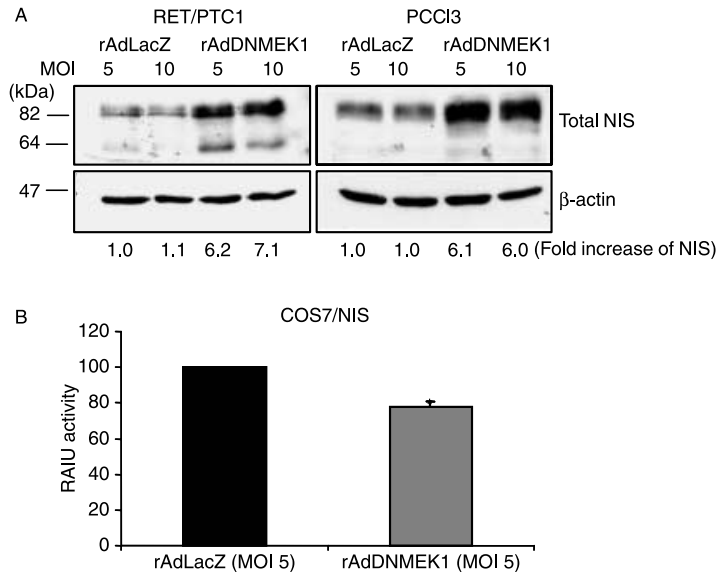

Figure 5 Adenovirus infection of dominant negative MEK1 (A217/A221) increases NIS protein levels in thyroid cells and decreases RAIU activity in COS7 cells expressing exogenous NIS. Cells were infected with either recombinant adenovirus carrying LacZ (rAdLacZ) or dominant negative MEK1 (rAdDNMEK1) at the indicated multiplicity of infection (MOI) for $48 \mathrm{~h}$ prior to western blot analysis or RAIU assays. A: Total NIS protein levels were increased by rAdDNMEK1 infection in both RET/PTC1-expressing cells and parental PCCl3 cells. Densitometry analysis was performed to determine the fold increase of total NIS normalized with $\beta$-actin. The results are representative of two independent experiments. B: NISmediated RAIU activity was reduced by $22 \%$ in COS7/NIS cells infected with rAdDNMEK1. The results represent the average and range of two independent experiments performed in triplicate. Asterisks denote statistically significant difference in comparison with DMSO-treated cells $(P<0.05)$.

COS7/NIS cells. As shown in Fig. 7A, the change in total or cell surface $\mathrm{Na}^{+} / \mathrm{K}^{+}$-ATPase levels by PD98059 is minimal in all the three cell lines. Nevertheless, PD98059 reduced $\mathrm{Na}^{+} / \mathrm{K}^{+}$-ATPase activity (by $15-18 \%$ ), as measured by ouabainsensitive ${ }^{86} \mathrm{Rb}$ uptake activity, in all the three cell lines (Fig. 7B). The decreased $\mathrm{Na}^{+} / \mathrm{K}^{+}$-ATPase activity may lead to decreased $\mathrm{Na}^{+}$gradient and consequently decreased NIS-mediated RAIU activity.

Table 1 PD98059 does not alter NIS $K_{\mathrm{m}}-\mathrm{I}^{-}$

\begin{tabular}{lll}
\hline Cell lines & Control & PD98059 \\
\hline RET/PTC1 & $88.5 \pm 28.9$ & $90.5 \pm 41.7$ \\
PCCI3 & $77.0 \pm 1.4$ & $75.5 \pm 7.8$ \\
COS7/NIS & $55.0 \pm 2.8$ & $59.0 \pm 5.6$ \\
\hline
\end{tabular}

Table 2 PD98059 decreases NIS $\mathrm{V}_{\max }-\mathrm{I}^{-}$

\begin{tabular}{ll}
\hline Cell lines & Decreased $\boldsymbol{V}_{\max }(\%)$ \\
\hline RET/PTC1 & $74.0 \pm 12.5$ \\
$\mathrm{PCCl3}$ & $74.0 \pm 14.5$ \\
COS7/NIS & $65.5 \pm 6.4$ \\
\hline
\end{tabular}



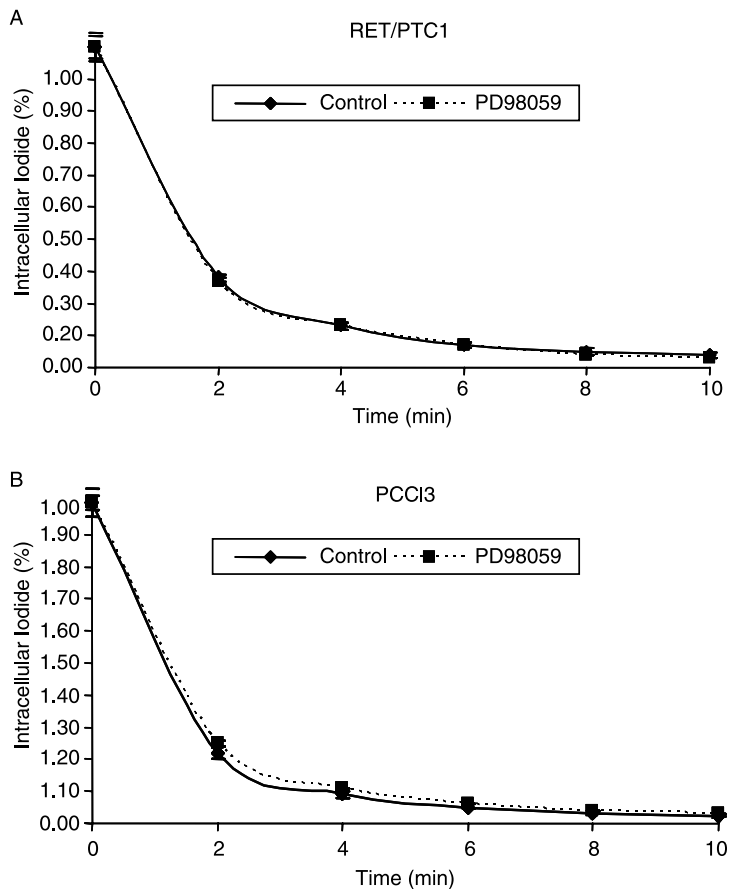

Figure 6 PD98059 does not increase the rate of iodide efflux in either A: RET/PTC1-expressing cells or B: parental PCCl3 cells. Cells were treated with $40 \mu \mathrm{M}$ PD98059 for $4 \mathrm{~h}$ prior to iodide efflux studies. Each data point was performed in triplicate and the mean \pm S.D. are shown. The results are representative of three independent experiments.

\section{Ouabain titration indicates that the extent of decrease in $\mathrm{Na}^{+} / \mathrm{K}^{+}$-ATPase activity is much greater than the extent of decrease in RAIU activity}

We performed ouabain titration to investigate whether a $15 \%$ reduction in $\mathrm{Na}^{+} / \mathrm{K}^{+}$-ATPase activity is accompanied with a $25-38 \%$ reduction in RAIU activity in RET/PTC1-expressing cells. While ouabain decreased both $\mathrm{Na}^{+} / \mathrm{K}^{+}$-ATPase and RAIU activities (Fig. 8), the extent of decrease in $\mathrm{Na}^{+} / \mathrm{K}^{+}$-ATPase activity is much greater than the extent of decrease in RAIU activity. For example, at $50 \mu \mathrm{M}$ ouabain, $\mathrm{Na}^{+}$/ $\mathrm{K}^{+}$-ATPase activity was decreased by $16 \%$, yet RAIU activity was only decreased by $7 \%$. Thus, the effect of PD98059 on decreasing RAIU activity cannot be solely contributed by its effect on decreasing $\mathrm{Na}^{+} / \mathrm{K}^{+}$ATPase activity in RET/PTC1-expressing cells. It appears that MEK inhibition reduced both $\mathrm{Na}^{+} / \mathrm{K}^{+}$ATPase and RAIU activities, yet without one being the cause of the other. To further investigate whether a decrease in $\mathrm{Na}^{+} / \mathrm{K}^{+}$-ATPase activity is always accompanied with a decrease in the functional activity of $\mathrm{Na}^{+}$-dependent co-transporter, we examined the effects of PD98059 on the functional activity of $\mathrm{Na}^{+}$dependent multivitamin transporter (SMVT). SMVT is also a member of the sodium-dependent solute family member and shares high homology with NIS. As shown in Fig. 9A, PD98059 increased, rather than decreasing, biotin uptake activity in SMVT-expressing COS7 cells despite decreasing $\mathrm{Na}^{+} / \mathrm{K}^{+}$-ATPase activity (Fig. 9B). Thus, the decrease of NIS-mediated RAIU activity by PD98059 is unlikely due to the decrease of $\mathrm{Na}^{+}$gradient.

\section{Discussion}

In this study, we found that MEK inhibition increases NIS protein levels in RET/PTC1- and MEK-expressing $\mathrm{PCCl} 3$ rat thyroid cells, as well as in parental $\mathrm{PCCl} 3$ cells. Unexpectedly, the increase of NIS protein level was not accompanied with an increase in NISmediated RAIU activity, particularly at early time points of PD98059 treatment. The transient decrease of RAIU activity by PD98059 in thyroid cells was not due to decreased NIS cell surface level, decreased NIS binding affinity for $\mathrm{I}^{-}$, increased iodide efflux, or decreased $\mathrm{Na}^{+}$gradient. Since PD98059 reduced $V_{\max }-\mathrm{I}^{-}$without decreasing NIS cell surface levels, it is most likely that PD98059 decreases the turnover rate of iodide transport with an yet to be identified mechanism.

It is well established that NIS expression and function in thyroid cells are mainly stimulated by thyroid-stimulating hormone/thyrotropin (TSH), which acts primarily through cAMP (Weiss et al. 1984, Kaminsky et al. 1994, Kogai et al. 1997, Levy et al. 1997, Saito et al. 1997, Riedel \& Carrasco 2001). Recent studies demonstrated that NIS expression, as well as the expression of thyroglobulin and thyroid peroxidase, is inhibited by Raf/MEK/ERK signaling pathway (Kupperman et al. 1996, Miller et al. 1998, Knauf et al. 2003). Indeed, in both PCCl3 and WRT rat thyroid cells, TSH preferentially activates the Ras/PI3K signaling pathway instead of the Ras/Raf/MEK/ERK pathway (Al-Alawi et al. 1995, Miller et al. 1998, Ciullo et al. 2001). Moreover, TSH-stimulated NIS expression is blocked in cells transiently expressing Ras effector mutant (rasV12S35) that signals preferentially through Raf-1 (Cass \& Meinkoth 2000). In Ras- or RET/PTCtransformed thyroid cells, NIS promoter activity (Missero et al. 2000) as well as NIS mRNA levels (Knauf et al. 2003) was decreased primarily through MEK activation. In this study, we further confirmed that RET/PTC1 reduces NIS protein levels primarily mediated by the MEK signaling pathway (Fig. 1), and 

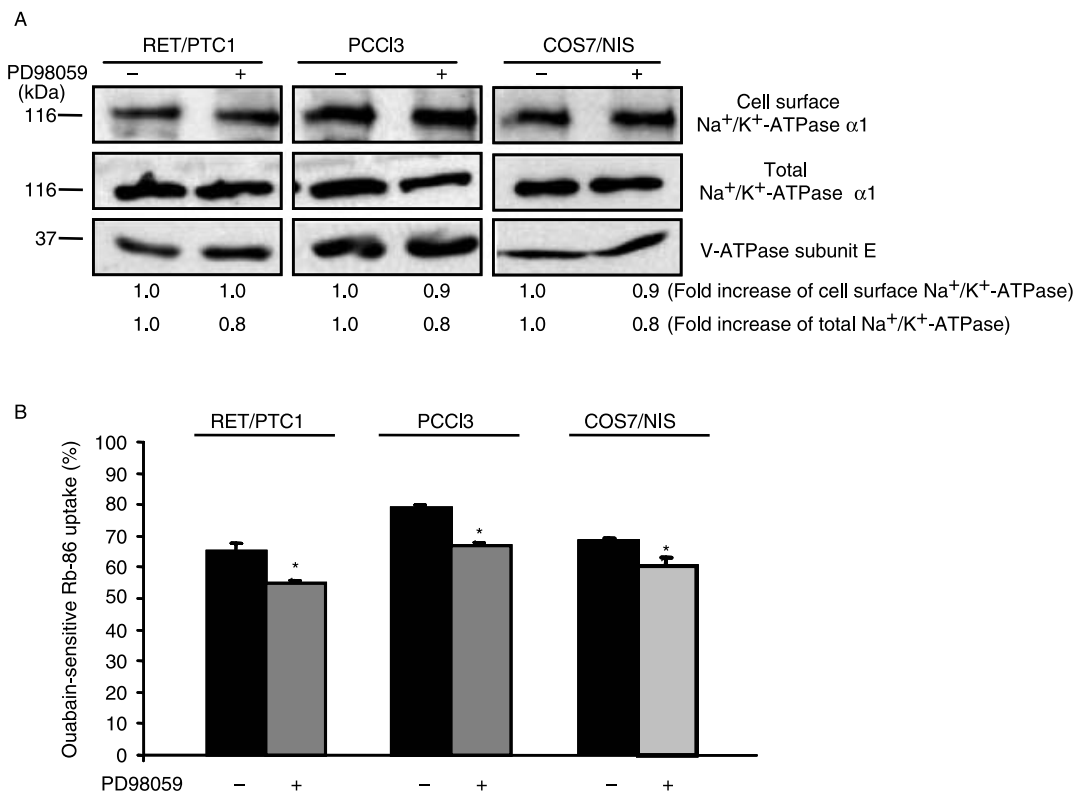

Figure 7 PD98059 decreases $\mathrm{Na}^{+} / \mathrm{K}^{+}$-ATPase activity in RET/PTC1-expressing cells, parental PCCl3 cells, and COS7 cells expressing exogenous NIS. Cells were treated with $40 \mu \mathrm{M}$ PD98059 for $4 \mathrm{~h}$ prior to western blot analysis or ouabain-sensitive ${ }^{86} \mathrm{Rb}$ uptake assays. A: Western blot analysis showed that the change in total or cell surface $\mathrm{Na}^{+} / \mathrm{K}^{+}$-ATPase levels by PD98059 was minimal in all the three cell lines. Densitometry analysis was performed to determine the fold increases of cell surface and total $\mathrm{Na}^{+} / \mathrm{K}^{+}$-ATPase $\alpha_{1}$ normalized with V-ATPase. The results are representative of two independent experiments. B: Treatment of PD98059 for $4 \mathrm{~h}$ decreased ouabain-sensitive ${ }^{86} \mathrm{Rb}$ uptake in all the three cell lines. PD98059 decreased $\mathrm{Na}^{+} / \mathrm{K}^{+}$-ATPase activity in RET/PTC1-expressing cells and parental PCCl3 cells by $15 \%$, and in COS7/NIS cells by $18 \%$. Each data point was performed in triplicate and the mean \pm s.D. are shown. The results are representative of two independent experiments. Asterisks denote statistically significant difference in comparison with DMSO-treated cells $(P<0.05)$.

that MEK activation is sufficient to reduce NIS protein levels (Fig. 2) in $\mathrm{PCCl} 3$ rat thyroid cells. Interestingly, PD98059 appears to increase NIS protein levels to a greater extent in RET/PTC1-expressing cells (where MEK signaling is constitutively activated) than in parental PCCl3 cells (where MEK is not constitutively activated).

Paradoxically, while NIS protein levels were increased readily by PD98059, NIS-mediated RAIU activity was transiently decreased in RET/PTC1expressing cells as well as in parental $\mathrm{PCCl} 3$ cells. While we could not exclude the possible off-target effects of PD98059, we believe that the effect of PD98059 on NIS expression/activity was mainly mediated by MEK inhibition. Not only were similar results obtained using a structurally unrelated MEK inhibitor U0126 (data not shown), but cells infected with rAdDNMEK1 also had increased NIS expression and decreased RAIU activity. The decrease of RAIU activity by MEK inhibition was not restricted to thyroid cells, as MEK inhibition also decreased RAIU activity in non-thyroid cells expressing exogenous NIS.

We showed that the decrease in RAIU activity by PD98059 was not contributed by decrease in NIS cell

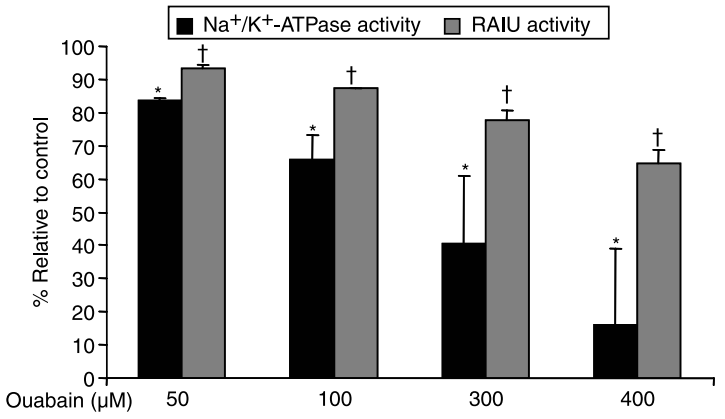

Figure 8 Ouabain titration decreases $\mathrm{Na}^{+} / \mathrm{K}^{+}$-ATPase activity to a much greater extent than RAIU activity in RET/PTC1expressing cells. Cells were treated with varying concentrations of ouabain as indicated prior to ouabain-sensitive ${ }^{86} \mathrm{Rb}$ uptake or RAIU assays. Ouabain at 50,100,300, and $500 \mu \mathrm{M}$ decreased $\mathrm{Na}^{+} / \mathrm{K}^{+}$-ATPase activity by $16,34,60$, and $84 \%$ respectively. In comparison, ouabain at $50,100,300$, and $500 \mu \mathrm{M}$ only decreased RAIU activity by $7,13,22$, and $35 \%$ respectively. Each data point was performed in triplicate and the mean \pm s.D. are shown. The results are representative of two independent experiments. Asterisks and dagger denotes statistically significant difference in comparison with DMSOtreated cells $(P<0.05)$, ouabain-sensitive ${ }^{86} \mathrm{Rb}$ uptake $\left({ }^{*}\right)$, or RAIU assays $(\dagger)$. 
A

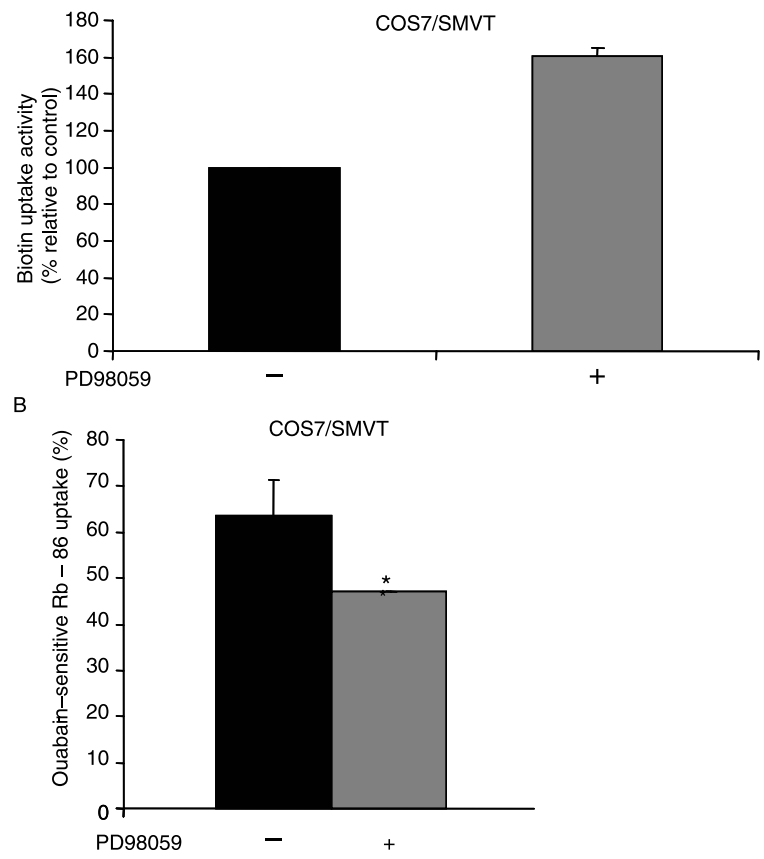

Figure 9 PD98059 increases SMVT-mediated biotin uptake activity, despite decreasing $\mathrm{Na}^{+} / \mathrm{K}^{+}$-ATPase activity, in COS7 cells expressing exogenous SMVT. Cells were treated with $40 \mu \mathrm{M}$ PD98059 for $4 \mathrm{~h}$ prior to $\left[{ }^{3} \mathrm{H}\right]$ biotin uptake assay or ouabain-sensitive ${ }^{86} \mathrm{Rb}$ uptake assay. (A) PD98059 increased biotin uptake activity in COS7/SMVT cells. The results represent the mean \pm s.D. of three independent experiments performed in triplicate. Asterisks denote statistically significant difference in comparison with DMSO-treated cells $(P<0.05)$. (B) PD98059 decreased ouabain-sensitive ${ }^{86} \mathrm{Rb}$ uptake in COS7/SMVT cells about $22 \%$. The results represent the mean \pm s.D. of three independent experiments performed in triplicate. Asterisks denote statistically significant difference in comparison with DMSO-treated cells $(P<0.05)$.

surface levels, decrease in NIS binding affinity for $\mathrm{I}^{-}$, or increase in the rate of iodide efflux. During the preparation of this manuscript, Riesco-Eizaguirre et al. (2006) reported that $\mathrm{BRAF}^{\mathrm{V} 600 \mathrm{E}}$ expression decreased NIS protein levels and impaired NIS targeting to the cell surface, and that MEK inhibitor U0126 readily increased NIS protein levels, but was not able to completely restore NIS cell surface levels in $\mathrm{BRAF}^{\mathrm{V} 600 \mathrm{E}}$-expressing $\mathrm{PCCl} 3$ cells in the time period examined. Together with our study, it is clear that NIS protein levels are readily increased by MEK inhibition in thyroid cells expressing RET/PTC1, B-RAF ${ }^{\mathrm{V} 600 \mathrm{E}}$, or MEK1 (E217/E221). However, NIS cell surface trafficking as well as NIS-mediated RAIU activity appears to lag behind the increase of NIS protein levels.

Several studies have indicated that MEK/ERK signaling is involved in modulation of $\mathrm{Na}^{+} / \mathrm{K}^{+}$-ATPase activity by various hormones (Isenovic et al. 2004, Khundmiri et al. 2004, Zhong et al. 2004, Khundmiri et al. 2005). Our study confirmed that MEK/ERK signaling is essential for optimal $\mathrm{Na}^{+} / \mathrm{K}^{+}$-ATPase activity in many cell types, as PD98059 decreased ouabain-sensitive ${ }^{86} \mathrm{Rb}$ uptake activity in all cell lines we investigated. However, the findings that ouabain decreased $\mathrm{Na}^{+} / \mathrm{K}^{+}$-ATPase activity to a much greater extent than RAIU activity and that PD98059 increased SMVT-mediated biotin uptake activity despite $\mathrm{Na}^{+} /$ $\mathrm{K}^{+}$-ATPase activity indicate that the decrease in RAIU activity by PD98059 was not contributed by a decrease in $\mathrm{Na}^{+}$gradient. Thus, it is most likely that PD98059 modulates NIS activity by post-translational modifications, such as changes in protein phosphorylation or recruitment of the NIS protein to lipid rafts. We are currently in the process of examining this possibility.

In summary, our study showed that MEK inhibition increases NIS protein levels, but transiently decreases NIS-mediated RAIU activity, in RET/PTC1-transformed thyroid cells as well as in parental $\mathrm{PCCl} 3$ cells. This finding is of clinical significance, as it indicates that MEK inhibition is sufficient to increase NIS protein levels, but may not be effective in restoring NIS-mediated RAIU activity in papillary thyroid carcinomas harboring RET/PTC, Ras, or B-Raf mutations. Most importantly, our study uncovers that MEK signaling modulates not only NIS expression, but also NIS-mediated RAIU activity. Further study identifying MEK downstream signaling that differentially modulates NIS expression from functional activity is warranted. In doing so, novel strategies can be developed to increase NIS expression as well as NIS-mediated RAIU activity in advanced thyroid carcinomas.

\section{Acknowledgements}

We wish to thank Drs Beth Lee and Bernard Rousset for providing us with an antibody against the $\mathrm{E}$ subunit of V-ATPase and an antibody against rat NIS respectively. We would like to thank Drs Jeffrey A Knauf and James A Fagin for providing us with $\mathrm{PCCl} 3$ cells with doxycycline-inducible MEK1 (E217/E221) expression. We would also like to thank Dr Puttur D Prasad for providing us with human SMVT cDNA. This work was supported in part by NIH NIBIB 1 R01 EB001876 (to S M J). The authors declare that there is no conflict of interest that would prejudice the impartiality of this scientific work. 


\section{References}

Al-Alawi N, Rose DW, Buckmaster C, Ahn N, Rapp U, Meinkoth J \& Feramisco JR 1995 Thyrotropin-induced mitogenesis is Ras dependent but appears to bypass the Raf-dependent cytoplasmic kinase cascade. Molecular and Cellular Biology 15 1162-1168.

Alessi DR, Cuenda A, Cohen P, Dudley DT \& Saltiel AR 1995 PD 098059 is a specific inhibitor of the activation of mitogen-activated protein kinase kinase in vitro and in vivo. Journal of Biological Chemistry $\mathbf{2 7 0}$ 27489-27494.

Arturi F, Russo D, Schlumberger M, du Villard JA, Caillou B, Vigneri P, Wicker R, Chiefari E, Suarez HG \& Filetti S 1998 Iodide symporter gene expression in human thyroid tumors. Journal of Clinical Endocrinology and Metabolism 83 2493-2496.

Arturi F, Russo D, Giuffrida D, Schlumberger M \& Filetti S 2000 Sodium-iodide symporter (NIS) gene expression in lymph-node metastases of papillary thyroid carcinomas. European Journal of Endocrinology 143 623-627.

Buckwalter TL, Venkateswaran A, Lavender M, La Perle KM, Cho JY, Robinson ML \& Jhiang SM 2002 The roles of phosphotyrosines-294, -404, and -451 in RET/PTC1induced thyroid tumor formation. Oncogene 21 8166-8172.

Cass LA \& Meinkoth JL 2000 Ras signaling through PI3K confers hormone-independent proliferation that is compatible with differentiation. Oncogene 19 924-932.

Cho JY, Sagartz JE, Capen CC, Mazzaferri EL \& Jhiang SM 1999 Early cellular abnormalities induced by RET/PTC1 oncogene in thyroid-targeted transgenic mice. Oncogene 18 3659-3665.

Ciullo I, Diez-Roux G, Di Domenico M, Migliaccio A \& Avvedimento EV 2001 cAMP signaling selectively influences Ras effectors pathways. Oncogene 20 1186-1192.

Dohan O, Gavrielides MV, Ginter C, Amzel LM \& Carrasco $\left.\mathrm{N} 2002 \mathrm{Na}\left(^{+}\right) / \mathrm{I}^{-}\right)$symporter activity requires a small and uncharged amino acid residue at position 395. Molecular Endocrinology 16 1893-1902.

Eskandari S, Loo DD, Dai G, Levy O, Wright EM \& Carrasco N 1997 Thyroid $\mathrm{Na}^{+} /$I symporter. Mechanism, stoichiometry, and specificity. Journal of Biological Chemistry 272 27230-27238.

Isenovic ER, Jacobs DB, Kedees MH, Sha Q, Milivojevic N, Kawakami K, Gick G \& Sowers JR 2004 Angiotensin II regulation of the $\mathrm{Na}^{+}$pump involves the phosphatidylinositol-3 kinase and p42/44 mitogen-activated protein kinase signaling pathways in vascular smooth muscle cells. Endocrinology 145 1151-1160.

Jhiang SM 2000 The RET proto-oncogene in human cancers. Oncogene 19 5590-5597.

Jhiang SM, Cho JY, Furminger TL, Sagartz JE, Tong Q, Capen CC \& Mazzaferri EL 1998 Thyroid carcinomas in RET/PTC transgenic mice. Recent Results in Cancer Research 154 265-270.
Kaminsky SM, Levy O, Salvador C, Dai G \& Carrasco N $\left.1994 \mathrm{Na}^{+}\right)$-I-symport activity is present in membrane vesicles from thyrotropin-deprived non-I( -$)$-transporting cultured thyroid cells. PNAS 91 3789-3793.

Khundmiri SJ, Bertorello AM, Delamere NA \& Lederer ED 2004 Clathrin-mediated endocytosis of $\mathrm{Na}^{+}, \mathrm{K}^{+}$-ATPase in response to parathyroid hormone requires ERK-dependent phosphorylation of Ser-11 within the alpha1-subunit. Journal of Biological Chemistry 279 17418-17427.

Khundmiri SJ, Dean WL, McLeish KR \& Lederer ED 2005 Parathyroid hormone-mediated regulation of $\mathrm{Na}^{+}-\mathrm{K}^{+}$ATPase requires ERK-dependent translocation of protein kinase Calpha. Journal of Biological Chemistry 280 8705-8713.

Knauf JA, Kuroda H, Basu S \& Fagin JA 2003 RET/PTCinduced dedifferentiation of thyroid cells is mediated through Y1062 signaling through SHC-RAS-MAP kinase. Oncogene 22 4406-4412.

Kogai T, Endo T, Saito T, Miyazaki A, Kawaguchi A \& Onaya T 1997 Regulation by thyroid-stimulating hormone of sodium/iodide symporter gene expression and protein levels in FRTL-5 cells. Endocrinology 138 2227-2232.

Kupperman E, Wofford D, Wen W \& Meinkoth JL 1996 Ras inhibits thyroglobulin expression but not cyclic adenosine monophosphate-mediated signaling in Wistar rat thyrocytes. Endocrinology 137 96-104.

Lazar V, Bidart JM, Caillou B, Mahe C, Lacroix L, Filetti S \& Schlumberger M 1999 Expression of the $\mathrm{Na}^{+} / \mathrm{I}^{-}$ symporter gene in human thyroid tumors: a comparison study with other thyroid-specific genes. Journal of Clinical Endocrinology and Metabolism 84 3228-3234.

Levy O, Dai G, Riedel C, Ginter CS, Paul EM, Lebowitz AN \& Carrasco N 1997 Characterization of the thyroid $\mathrm{Na}^{+} / \mathrm{I}^{-}$symporter with an anti-COOH terminus antibody. PNAS 94 5568-5573.

Marsee DK, Venkateswaran A, Tao H, Vadysirisack D, Zhang Z, Vandre DD \& Jhiang SM 2004 Inhibition of heat shock protein 90, a novel RET/PTC1-associated protein,increases radioiodide accumulation in thyroid cells. Journal of Biological Chemistry 279 43990-43997.

Miller MJ, Rioux L, Prendergast GV, Cannon S, White MA \& Meinkoth JL 1998 Differential effects of protein kinase A on Ras effector pathways. Molecular and Cellular Biology 18 3718-3726.

Missero C, Pirro MT \& Di Lauro R 2000 Multiple ras downstream pathways mediate functional repression of the homeobox gene product TTF-1. Molecular and Cellular Biology 20 2783-2793.

Riedel C, Levy O \& Carrasco N 2001 Post-transcriptional regulation of the sodium/iodide symporter by thyrotropin. Journal of Biological Chemistry 276 21458-21463.

Riesco-Eizaguirre G, Gutierrez-Martinez P, Garcia-Cabezas MA, Nistal M \& Santisteban P 2006 The oncogene BRAFV600E is associated with a high risk of recurrence 
and less differentiated papillary thyroid carcinoma due to the impairment of $\mathrm{Na}^{+} / \mathrm{I}^{-}$targeting to the membrane.

Endocrine-Related Cancer 13 257-269.

Saito T, Endo T, Kawaguchi A, Ikeda M, Nakazato M, Kogai T \& Onaya $\mathrm{T} 1997$ Increased expression of the $\mathrm{Na}^{+} / \mathrm{I}^{-}$ symporter in cultured human thyroid cells exposed to thyrotropin and in Graves' thyroid tissue. Journal of Clinical Endocrinology and Metabolism 82 3331-3336.

Trapasso F, Iuliano R, Chiefari E, Arturi F, Stella A, Filetti S, Fusco A \& Russo D 1999 Iodide symporter gene expression in normal and transformed rat thyroid cells. European Journal of Endocrinology 140 447-451.

Venkateswaran A, Marsee DK, Green SH \& Jhiang SM 2004 Forskolin, 8-Br-3 $3^{\prime}, 5^{\prime}$-cyclic adenosine $5^{\prime}$-monophosphate, and catalytic protein kinase A expression in the nucleus increase radioiodide uptake and sodium/iodide symporter protein levels in RET/PTC1-expressing cells. Journal of Clinical Endocrinology and Metabolism 89 6168-6172.

Weiss SJ, Philip NJ, Ambersi-Impiombato FS \& Grollman EF 1984 Thyrotropin-stimulated iodide transport mediated by adenosine $3^{\prime}, 5^{\prime}$-monophosphate and dependent on protein synthesis. Endocrinology 114 1099-1107.

Zhong Z, Kotova O, Davidescu A, Ehren I, Ekberg K, Jornvall H, Wahren J \& Chibalin AV 2004 C-peptide stimulates $\mathrm{Na}^{+}, \mathrm{K}^{+}$-ATPase via activation of ERK1/2 MAP kinases in human renal tubular cells. Cellular and Molecular Life Sciences 61 2782-2790. 